\title{
IRAN-AFRICA RELATIONS: OPPORTUNITIES AND PROSPECTS FOR IRAN
}

\section{Fátima Chimarizeni ${ }^{1}$}

In a political world featured by many sorts of alliances, Iran has sought the gathering of power in order to defend itself from economic sanctions imposed upon it by United States of America along with other members of the United Nations such as United Kingdom, France, Russia and China. Its turn towards Africa was one of the way-out strategies taken by Ahmadinejad in order to overcome the negative economic impact originated from the sanctions. Nonetheless, the rise to power of a leadership seemingly more turned to solve the nuclear issue directly with the Western states places the Iran-Africa Relationship in a fragile condition considering Iran's foreign policy priorities.

The time-frame of this work encompasses the year 2006. By then, the United Nations Security Council (UNSC) had passed the Resolution I696 on Iran aimed at pressuring Iran to stop its uranium enrichment program. Although that was not the first wave of sanctions the country faced, it stood as the first measure taken by the international group that has brought with it political, economic and social consequences for Iran. One of them is the partial economic isolation of Iran from the vast world market.

2015 was chosen because, on that year, the United Nations adopted Security Council Resolution 223I setting out a schedule for the suspension and eventual lift of UN sanctions against that country. During the period under study, most western countries avoided economic, diplomatic and military relations with Iran bringing economic hardships to that country. In order to lessen those hardships, Iran turned to its traditional allies such as China and Russia. Apart from that, Iran turned its eyes to Africa where it looked for political and diplomatic support and economic relations in

I Course of International Relations and Diplomacy, Higher Institute of International Relations of Mozambique, Maputo, Mozambique. E-mail: fatimacardoso3ı@gmail.com 
order to relieve the burden imposed by the sanctions as Western states were unanimous in their diplomatic pressure against Iran for, they regarded the Iranian nuclear issue as a direct threat against them.

The specific aim was to achieve a further understanding of the opportunities and prospects resulting from the Iranian foreign policy directed toward the African continent, specifically to the Western and Eastern regions of Africa. Iran has resorted to some African states in order to set itself away from the isolation it is compelled to face (Taylor 2010). By 2008 for instance, President Mahmoud Ahmadinejad expressed his willingness to strengthen Iranian relations with African states apart from those Iran had already relations with (Murithi 2013). Indeed, the Iranian foreign policy was driven towards promoting a feverish interaction between Iran and some African countries from 2005 onwards (Warner 20II).

In this work, I argue that, although the central actor of the Iranian political power is the Supreme Leader, the president is considered a key player as he is able to draw the domestic and international policies according to what he defines as priority, even though in a constrained domestic political environment. Although Iran keeps its relations with Africa, a sizeable change characterizes that relation. Nonetheless, the strategic relevance of the Iranian partnership with the African states is well known and preserved by Iran. Obviously, the major interest of the Rouhani administration was to free Iran from isolation.

Therefore, recently Iranian's foreign policy has been massively focused on resolving the nuclear issue compared to other issues. Nonetheless, it is up to president Rouhani to ensure or not a deep degree of Iranian engagement in Africa. That is, though the nuclear negotiations are as important as making partners, it is a Rouhani challenge to retain strong ties between Iran and African states while responding to the Western demands on the nuclear issue. Thus, Iran could get the opportunity to assure the African states partnership and it could rely on them in order to guarantee its influence and presence in the region.

The work has used the qualitative research design in which the triangulation method was applied. An analyst triangulation was used. It aimed at interpreting the different ways of seeing the data on Iran foreign policy toward Africa raised by different authors. Likewise, a data analysis of secondary sources of information such as e-journals, books and journal was applied. The main goal was to bring about a clear understanding of West and East Africa's relationship with Iran. Therefore, due to their particularity of holding both economic and military relations with Iran, states of those regions such as Nigeria, Senegal, Sudan and Eritrea were taken as object of analysis. Basically, an analysis of the Iranian foreign policy toward those 
regions and the response of those African states were analysed.

\section{Domestic Problems and External Solutions: Iran's resorting to Africa}

As most of the countries in the International System, economic and social issues influence Iran's domestic and foreign politics (Karshenas \& Hakimian 2008). Internally, the economic sanctions imposed on it have negatively impacted its economy (Zangeneh 2003) ${ }^{2}$. Actually, its economy has been declining since mid of I970s. The Iranian economy has relied mostly on the oil industry (Karshenas \& Hakimian 2008). However, due to sanctions, the oil industry has crumbled. The fact that its economy relies on only one commodity turns the Iranian economic situation complicated as there is no diversification, in terms of its produced goods for exports. Likewise, there is little number of skilled workers. Therefore, its productivity level is low. As a result unemployment level is rampant and living standard is at the lowest level (Karshenas \& Hakimian 2008).

Therefore, as a survival strategy to overcome its domestic problems, Iran strengthened its relations with states which held good political and economic relations, such as Russia, China and some African States. Taking it into consideration, the Western states have drawn a line which Iran has to cross in order for them to ease the sanctions and re-establish the normal economic and political relations with it. Iran at some points in time has been willing to do otherwise. Visibly it has seen itself, therefore, in need of resorting to other states in order to guarantee its survival, domestically and internationally. So, here come the African states.

African states such as Nigeria, Senegal, Eritrea, and Sudan have been basically facing common challenges related to the low level of their socio-economic development. Those states regard their poor condition as somehow a legacy of colonization (Nyikal 2005). Thus, they have seen Iran as a partner for solving together those problems as it has also undergone through external influence in the past and can retain resources that can

2 Since 2006 , four waves of economic sanctions have been imposed on Iran. In December 2006, after Tehran's failure to comply incentives endorsed by the UNSC, the Council imposed sanctions on Iran's trade in sensitive nuclear materials and technology. In 2007 , the previous sanctions were intensified through a package whereby specific officials were named as targets of the sanctions and additional sanctions were added against Iranian financial institutions. In March 2008, the Security Council passed Resolution I803 to reaffirm and uphold previous sanctions. And, by April 2010, it appeared that Russia and China - Iran's traditional supporters on the Security Council reconsidered their tolerance of Iran's nuclear program as the USA, France, and Great Britain pushed for a resolution approving more sanctions (Global Policy Forum 20I5). 
be deployed in their countries ${ }^{3}$. Thus, the establishment of cooperation in the economic and military sectors through the materialization of political agreements have shaped those states' relations. Thus, the security cooperation between Iran and some of the African states, for instance, has manifested through military assistance (Murithi 2013). Then, throughout those developing states' cooperation the rhetoric against the West is used, by Iran, as catalyst to spur that relationship (Murithi 2013; Rubin 20I3). Nonetheless, both sides need each other to assure the boost of their economic and military area.

Nonetheless, over the last couple of years, that commitment has visibly decreased under the rule of President Hassan Rouhani, regardless of his past public expression affirming his willingness to expand it (Chimbelu 20I0). As such, given the essential role the African states hold as Iranian partners overseas as well as the substantial variation of the Iranian political standing towards those partners, resulting from different policies chosen by the current president, the question to what extent the president is influential on drawing out the Iranian foreign politics towards Africa should be considered.

\section{Historical Perspective of Iran and Africa Relations}

Deep historical ties characterize the relationship between Iran and Africa. Their relationship, essentially, goes back to the era of Empire. Back in ninth century Persia-African relations were mostly featured by trade between both people: Persian and African (Murithi 2013). By the I6th century, there were Persian migrants settlements in urban areas in East Africa as well as visits of Persian merchants therein (Murithi 20I3). During the Pahlavi Shah Era, the relationship was featured by good economic relations between Iran and some African states, such as South Africa (Onderco 20I2).

Hence, based on what have been some of the main driving factors in Iran's relationship with Africa, its anti-imperialism conception of foreign policy for instance, the Islamic state even supported some African independence movements. The I974 Iranian oil revenue surplus was used to support that cause. Even South African movements benefited from it. Therefore, energy and common political standing have been some of the driving factors in Iran's relationship with Africa.

In the aftermaths of the Islamic Revolution (I979), the Iranian

3 Although Iran faces economic problems its level of development allows it to interact with other states and share the knowledge in different areas it has held. Then, Iran is not as developed as the Western states; however, it holds experience in technical and military sectors which are shared with other states it cooperates with. 
foreign policy towards Africa was featured by continuity. In fact, there has been noticeable continuation regarding the preservation of good relationship between African states and Iran. The succeeding leaders in Iran did not undermine the alliance Iran established with African states. Then, Iran-Africa relations have been featured by the use of political means by the former to reach out the latter (Rubin 20I3). The fact that both sides belonged to a non-alignment movement - holding the same conception of anti-imperialism and played the role of revolution bastion - stood as the main ideological factor that strengthened their relationship (Onderco 20I2). As a result of this stand taken by Iran, it holds a position of observer member in the African Union (AU). Through this position, Iran secures the support of some of the member states of AU as it has the ability to interact with as many of them as possible (Kobi 2OII). The consequences of those interactions are reflected in the observable alliance between Iran and some African states and their endless support to Iranian ventures in other organizations such as IAEA other than UN.

\section{Same Foreign Policy Role and more Partners}

Over the years, the Iran-Africa relationship has, in fact, evolved. Then, along with continuation of positive relations, there has been a considerable widening of range of African states interacting with Iran. Thus, Iran has interacted with states from each one of the African regions, mostly positively. This interaction entails different sorts of relations between both entities. It involves diplomatic, political, military and trade exchanges. It has, therefore, resulted in significant Iranian presence in Africa (ITIC 2009). It has aimed at fulfilling Iran's diplomatic, economic and religious goals (Haji-Yousefi 20I0).

Then, taking a non-alignment standing, the Iranian rhetoric against the West has allowed it to get some African states that share the same perception regarding it as partners. Additionally, the union of the developing states (based on South rhetoric) aiming to achieve economic growth stand as the pillar of the cooperation (Warner 2OII). Nevertheless, the efficiency of this interaction is rather questionable. Yet, official visits of diplomats from Iran to states such as Nigeria and Senegal as well as the other way around have increased (Modell \& Asher 2013; Taylor 2010).

Being the major power in West Africa, Nigeria's privileged position in key international institutions - such as its membership of the IAEA and the UNSC has led Iran to build up relation with it (Rubin 2013; Mcanenny 20I4). Thus, Iran has agreed to share nuclear technology for the production of electricity with Nigeria (Chimbelu 20I0). Furthermore, in June of 20I4, 
during a meeting headed by Iran's Minister of Industry and his Nigerian counterpart, the two nations agreed to seek closer cooperation in areas including mining, industry, oil, engineering, and nuclear technology (Mcanenny 20I4). This illustrates the tremendous political commitment shown by both parties in that regard.

Actually, Iran has been reaching out to African countries as it stands an entity which takes initiatives that are positively received by the African countries. Iran's actions in Senegal focus largely on economics, with an emphasis on promises of aid to set up factories and various projects (Chimbelu 20I0). Essentially, it includes the extension of a I20 million dollar line of credit from the Export Development Bank of Iran to Senegal for the purchase of Iranian tractors (Kobi 20II). For Taylor (20IO), those measures reflect the economic interests of the Senegalese elite. Nevertheless, Senegal has recently served as "Iran's gateway to Africa" as the USD I6 million in exports to Senegal in 2009 constituted a greater volume of trade than that of Iran and all other West African countries combined (Kobi 20II; Rubin 20I3).

Sudan has a geo-strategic location - lying in the Red Sea - that enhances its standing as Iran's strong ally in the East Africa Region (Mcanney 20I4). According to (ITIC 2009), the ultimate aim of the partnership is to enable Iran to establish an active naval presence in the Red Sea leading to the Gulf of Eilat and the Suez Canal. Through this, Iran is liable to exploit its use of the ports therein for any activity. It includes political activity against Israel, moderate Arab countries and to respond, should its nuclear facilities be attacked.

Additionally, there have been political agreements in the military sector between Iran and Sudan whereby the former has openly pledged to supply weaponry to the latter. Hence, the Sudanese defence minister after visiting Iran, in January 2007, affirmed in September 2007 that Iran was one of Sudan's main suppliers of weapons (ITCT 2009). According to Modell \& Asher (2013), Iran has entered into an agreement with Sudan to train Sudanese National Islamic Front troops and intelligence officers in Tehran as part of Sudan's effort to establish the Sudanese Popular Defense Forces. It has also built the Yarmouk Military Industrial Complex; an arms manufacturing facility bombed in October 2012, and has reportedly entered into several other joint military projects. All of it illustrates the deep bilateral military ties between both states.

With regard to Eritrea, one of the milestones in the relations between the two countries was the May 2008 visit of Isaias Afworki, the Eritrean president, to Iran and his meeting with Ahmadinejad. That meeting ended with the signing of agreements and Memorandum of Understanding 
between both entities (ITIC 2009). The scope of those agreements lay in the increasing of trade ties between Eritrea and Iran and expanding and encouraging Iranian investment in Eritrea's agricultural, mining, and energy sectors (Mcanenny 20I4). Resultantly, in 2008, the Iranian Bank for Export Development gave Eritrea \$35 million in credit to promote trade relations between the two countries. As gratitude, the Eritrean foreign minister expressed support for Iran's nuclear program when the Iranian minister visited the UN (ITIC 2009).

Notably, the major interest of the African countries here has been to get one more partner able to provide them the needed resources to solve their critical domestic problems. Facing dire rates of poverty, underdevelopment, and lack of security coupled with the existent political will and efforts to overcome that scenario, those countries see in Iran as one of gateway for these. Here, the sharing of common view of the world concerning the loaded dislike for the West as it bears the bad image of past imperialism stands as crucial incentive for the fostering of that relationship. Additionally, the military sector is taken as a relevant area to establish as well as enhance cooperation ties between the states above mentioned. Therefore it allows the consolidation of Iranian presence in some regions of Africa.

Moreover, worthy to note is the difference in existing degrees of interaction regarding Iran and the African states. As such, compared to other African regions, the East African and the West African states are the ones that have recently interacted most with Iran. Apart from sharing of historic ties with Iran, the East African states have recently shared political relations with it. Actually, states originated from those two African regions such as Eritrea, Sudan, Nigeria, Senegal and so on, have economic as well as military ties with Iran (Mcanenny 20I4). Sometimes, the religious component is also incorporated in those interactions (Kobi 20II).

Unlike them, the Sub-Saharan states such as Zimbabwe, Lesotho, Malawi, Malawi and Namibia have been interacting with Iran mostly in economic areas. Hence, the seeking of uranium in latter states by Iran, in order to supply its nuclear venture, constitutes its main interest therein (Onderco 20I2). The exchange of uranium deposits, thus, has been the condition put by Iran upon some African states in order to concede to them economic or even military resources (Solomon 2015). Resultantly, the outreach of the African mining states stands as one of the Iranian strategies towards the continent. 


\section{Iran's Engagement in Africa: A Foreign Policy Left in the Past?}

Basically, the raising of Iran's deep engagement with Africa has been witnessed since 2005. Then, the rise of President Ahmadinejad to power (2005-2013) transformed the dynamics of that relationship (Rubin 2013). Actually, that was reinforced through the enormous deployment of Iranian presence in Africa by political, economic, military and religious means (Kobi 20II; Mcanney 20I4). Here, the Ahmadinejad presidency, different from his predecessors, brought out a foreign policy of strong engagement with Africa which was materialized through Iran's excessive involvement in Africa (Rubin 20II). It aimed at securing the already existent alliance and making more allies therein. It was operationalized through Ahmadinejad's constant official visits to Africa; the African leaders' visits to Iran; as well as the Iran's hosting of an Iran-Africa Conference in Teheran in 2008. For ITIC (2009), those moves revealed Iran's seeking of allies in order to operationalize its national interests in the International System to establish itself as a regional power in the Middle East. It also meant an Iranian run away from the economic sanctions it had been subjected by the UNSC since 2006.

On one side of the relation stands Iran, providing those states with economic and military resources it holds, which it, can use to leverage its interests there. On the other hand, there is a process involving those states payback to Iran's "support". That is visibly materialized in terms of those states political allegiance as well as their support over resolutions against Iran in the United Nations (UN) as well as International Atomic Energy Agency (IAEA) when it comes to the contentious Nuclear Program; an issue in which Iran acutely needs their support.

The Iranian foreign policy for many years was featured by alliance between the external powers and a less autonomous state. Above and beyond, Iran's politics was based on the excessive dependence on the US aid, in order to preserve the political security of Mohammad Reza Shah. Over the years, the major concern of the Shah was to keep his own comfort zone (Haji-Yousefi 2010).

Nonetheless, only after its coming into existence as an Islamic Republic, the situation underwent a transformation. By this time, the foreign policy of Iran changed for a strongly autonomous one. It was clearly defined in its Constitution and noted through Iran's actions in the IS. Indeed, only after the establishment of an Islamic Republic, it effected a U turn in Iran s foreign policy. The new Constitution of the Islamic Republic was essentially a reflection of a new view of the new leaders governing Iran's politics. As 
such, based on article I52 of the new Constitution new principles upon which the country was to be governed, were laid down.

Thus, the religious element was introduced in Iran's politics by the Revolutionary leadership. Strikingly, it has since then been used as a vehicle to achieve Iran's national interests (DeLand 200I). It has been used for establishment of alliances regionally and transnationally. At the regional level, Iran has allied itself with state's leaders that share the same religious orientation. Then, its alliance with Syria stands as a reflection of that instance. Though Syria is not a theocratic state as Iran, the very fact that its president belongs to a Shiite segment of Islam confers him one of the premises to uphold relations with the Iranian regime. On the other hand, Iran has supported Islamic groups such as Hamas in Gaza Strip. Although the Shiite feature is not as fundamental for the sustainability of that relation, the spread of Islamic revolution stands as the main Iranian goal backing that organization. Iran holds the same pattern of interaction with its Middle East allies. That has, also, been exported to reach places beyond its regional borders. When coping with Africa, it is observed that Iran's pattern is followed. This is exemplified by the strong religious ties Iran holds with Sudan and Eritrea.

Nonetheless, some authors argue that Iran's foreign policy adopted since I979 is loaded with controversy. For some of them, the addition of religious elements brings out an ideological component of its foreign policy. Then, the ideological components have been placed in the lieu of the realistic ones as drivers of Iran's foreign policy (DeLand 200I; Ahmadi 2008).

This controversy can be found in Iran's I979 Constitution in Article 152. Yet the Iranian Constitution principles undoubtedly suggest that religion is as important to Iran as any other tool to drive its relation with other states (Ahmadi 2008). Indeed, none of those principles suggest that religion constitutes the crucial component of the Iranian foreign policy. Contrary, through analysis of the Iranian ventures in the IS, it can be noted that there is noticeable openness of various means to undertake its foreign policy in which the religion does not stand as a core component. This is certainly perceived by Iran's alliance with states, among many, such as Nigeria and Senegal, that are neither Islamic nor have Muslim people in the leadership front. It, in fact, shows the Iran's pursuance of its national interests.

As result of the negativity loaded in the US response to the Iranian supportive standing on fighting terrorism, the Iranian President, Ahmadinejad adopted a completely different posture from his predecessors, towards the US and the West (Ramazani 2009). Bearing in mind the heavy political atmosphere then, he turned to be confrontational towards the 
Western powers (Shanahan 2005). According to him, his predecessors were weak in dealing with the West and it was time for Iran to sort out its problems itself on the principle of independence from external powers' influence. Since then, the upheld Iranian approach of foreign policy was featured by a new trend. Hence, the "third world" states started to be seen as fundamental partners to establish alliance with Iran. This was, essentially, the materialization of the Third Worldism principle accurately stated in its I979 Constitution. Then, apart from Latin America, Africa was put into the reach of Iran's new external policies.

The recently elected Iranian president (2013), Hassan Rouhani, differently from his predecessor, has adopted another approach towards the West (Bazoobandi 20I4). Being conscious of the dire domestic economic situation thereby is directly affected by the heavy sanctions imposed on Iran's economy; he has expressed through many actions his strong will to revert this scenario. Thus, Rouhani strongly believes that the key to expand Iran's role in the region is to strengthen its economy. The economic sector is certainly one of the integral components of national power (Shanahan 2015). Then, one of the ways to achieve this economic interest, according to him, is the reaching of a comprehensive deal on the nuclear issue (Bazoobandi 20I4). As result of it is the pragmatic standing Iran has recently taken on the IS. Hence, the Rouhani administration has seen Iran's distancing from its previous direct confrontational stance as the suitable strategy to regain its international legitimacy as a state. His approach, then, has been strong on the resorting of diplomatic means of dialogue with the West instead of launching fierce threats as it was previously. Nonetheless, the above illustrated Iranian foreign policy's change of approach does not suggest its automatic change of interests in the IS. Instead, it has acknowledged the importance of the economic strength's primacy as a necessary condition to attain power politically.

\section{What about Africa?}

Resultantly, the new standing coming from the current Iranian leadership has undermined the existing Iran-Africa relations. Then, recently the "third worldism" principle transformed into action has been clearly weakened as more focus has been given to the Iranian nuclear deal with the West. Nonetheless, the strategic relevance of Africa for Iran has not changed. It is seen in the preservation of the ties it once had with those states in spite of the reduction of support.

Essentially, though the relationship between Iran and the African states has registered a considerable improvement during the Ahmadinejad 
era, the same involvement is not witnessed during the current Rouhani's presidency. Although Rouhani has expressed his willingness to keep Iran-Africa relations on the same path, the previous flexible relations between both are yet to come back to the previous stage or even gain new dynamic (Hammond 2013; PressTv 20I4). Accordingly, Rouhani has so far reaffirmed his commitment toward Africa. Nonetheless, that commitment is witnessed mostly in terms of political speeches. Actually, Rouhani's practical focus has been, instead, mostly on the nuclear issue than on concrete actions envisioning extending Iranian bonds with African states. Moreover, Rouhani's "engagement" with the West, instead of Africa, unlikely Ahmadinejad's one, puts Africa behind in respect to Iran's current foreign policy priorities.

The noticeable change on Rouhani's foreign policy approach clearly suggests the abandoning on emphasis of some of Iran's foreign policy principles, leading to enhancement of others. In order to secure Iran's economic interests, President Rouhani has opted to turn Iran's attention to the West underplaying the Third Worldism, a much praised principle by Ahmadinejad. Although, there was an officially expressed willingness to keep up the relations with the African states, he has manifestly been less engaged with African issues compared to Ahmadinejad. It clearly illustrates the reduction of Iran's economic participation in Africa. It also shows Iran's loss of the opportunity to enhance its presence in Africans regions.

In fact, Rouhani has neither travelled to Africa very often nor invited very often African officials to Iran, apart from the latest presence of his Prime Minister in Africa. Important to note is that, despite the decrease of direct contact with African states, the political and geo-strategic relevance of Africa to Iran remains unchanged. As such, the safeguarding of that stake will concretely remain as one of Iran's national interest, thus sustaining African relevance to Iran.

\section{Conclusion}

Although some of the African states have experienced a closer relationship with Iran, this trend has lately reduced. Evidently the complexity of Iranian domestic politics as well as the huge focus the Iranian government has deposed on the nuclear negotiations is curbing it from bolstering its relations with the African states, making it part of standby partners of Iran. It is more than clear that each president of Iran has driven Iran's foreign policy according to his own understanding of what should be the right path for Iran. In this regard, some of them have looked more or even less to some states in the International System. For the case of Iran relationship 
with the African states, Ahmadinejad had been defending, throughout his mandate, Iran's engagement with some of African states based in the conception of third Worldism that is stated in Iran's constitution. Nonetheless, not eliminating the principle, however not giving much attention in that is Rouhani, concerned with the well-being of Iranian state and adopting a more pragmatic standing. This standing consists of solving impediments of Iranian economic growth. To undertake this goal he has been compelled to relegate some Iran's allies to the second stage compared to the states involved in the negotiations of nuclear issue. An issue which if strategically solved may benefit Iran's economy through its adherence to the world economy with no need to face economic sanctions imposed by the international community.

\section{REFERENCES}

Ahmadi, Hamid. 2008. "Religious State and National Interest in Iran in the 2Ist Century: Politics Economics \& Conflict". In.: Iran in the 21st century. (Eds) Homa Khatouzian and Hossein Shahidi. Routledge. Oxon

Bazoobandi, Sara. 20I4. Iran's Regional Policy: Interests, Challenges and Ambitions. ISPI. Available at: http://www.ispionline.it/sites/default/ files/pubblicazioni/analysis_275_20I4_o.pdf

Chimbelu, Chiponda. 20I0. Iran Makes Inroads in Parts of Africa. Available at: http://www.dw.de/iran-makes-inroads-in-parts-ofafrica/a-5257032

DeLand, Janet. 200I. Fundamental Sources of Iranian Foreign and Security Policies. Available at: http://www.rand.org/content/dam/rand/ pubs/monograph_reports/MRi320/MRI320.ch2.pdf

Global Policy Forum. 2015. UN Sanctions against Iran. Available at: https://www.globalpolicy.org/security-council/ index-of-countries-on-the-security-council-agenda/iran.html

Haji-Youssefi, Amir M. 20I0. Iran's Foreign Policy During Ahmadinejad: From Confrontation to Accommodation. Available at: http:// www.cpsa-acsp.ca/papers-2oı//Haji-Yousefiı.pdf

Hammond, Joseph. 2013. Mahmoud Akmadnejad's African Safari. Available at: http://thediplomat.com/tag/iran-africa-relations/

ITIC. 2009. Iran's Activity in East Africa, the gateway to the Middle East and the African continent. Available at: http://www.terrorism-info.org. il/en/article/ı8244

Karshenas, Massoud; Hakimian, $\mathrm{H}$ a s s a $\mathrm{n}$. 
"Managing Oil Resources and Economic Diversification in Iran". In.: 21st Century Politics Economics and Conflict. Katouzian, Homa.; Shahidi, Hossein. Routledge, New York.

Kobi. 20II. Iran in Africa - Broken Promises, Terrorism and Drugs. Available at: http://archive.irandailybrief.com/wp-content/ uploads/20II/05/Iran-in-Africa.pdf

McAnenny, Alex. 20I4. Iran in Africa: A Tutorial Overview of Iran's Strategic Influence In Africa. Center for Security Policy. Available at: http:// www.centerforsecuritypolicy.org/wp-content/uploads/20I5/oI/Iran-inAfrica.pdf

Moddell, Scott; Asher, David. 2013. Countering the Iran Action Network. Center for a New American Security. Available at: http://www.cnas. org/files/documents/publications/CNAS_Pushback_ModellAsher_o.pdf

Murithi, Tim. 2013. Handbook of Africa's International Relations. Routledge. Oxon

Nyikal, Harold. 2005. Neo-Colonialism In Africa: The Economic Crisis in Africa and the Propagation of the Status Quo by the World Bank/ IMF And WTO. Available at: http://web.stanford.edu/class/e297a/NeoColonialism\%2oin\%2oAfrica.pdf

Onderco, Michael. 2012. “South Africa's Iran policy: “Poster child" Meets Renegade". South African Journal of International Affairs. Available at: http://www.tandfonline.com/action/ showCitFormats?doi=10.1080/10220461.2012.740I79

PressTv. 20I4. Iran Seeks Closer Ties with African States: Rouhani. Available at: http://www.presstv.com/detail/20I4/02/24/352108/iran-keento-expand-ties-with-africa/

Ramazani, R.K. 2009. Understanding Iranian Foreign Policy. Available at: mercury.ethz.ch/.../Files/ISN/.../ch_I_Undestanding_Iranian_FP.pdf

Rubin, Michael. 2013. Africa: Iran's Final Frontier? American Enterprise Institute for Public Policy Research. Available at: https://www. aei.org/publication/africa-irans-final-frontier/

Shanahan, Rodger. 2015. Iranian Foreign Policy under Rouhani. Lowy Institute. Available at: http://www.lowyinstitute.org/files/iranian-foreignpolicy-under-rouhani.pdf

Taylor, Ian. 20I0. The International Relations of Sub-Saharan Africa. The Continuum International Publishing Group. New York

Warner, Jason. 20II. Iran's Troubled Foray into Africa. Available at: http://globalpublicsquare.blogs.cnn.com/20II/ı/12/irans-troubled-forayinto-africa/ 
Zangeneh, Hamid. 2003. “The Iranian Economy and the Globalization Process". In.: Iran Encountering Globalization: Problems and Prospects. Ed. Ali Mohammadi, Routledge. Oxon

\section{ABSTRACT}

This paper describes the panorama of the relations between Iran and Africa through the years of 2006 and 2015. During the studied period, most western countries avoided economic, diplomatic and military actions with Iran, leading the country to economic hardships. In order to reduce this difficulties, Iran turned to its traditional allies, such as China and Russia and, especially, looked to the African continent, where it sought political and diplomatic support and the economic relations needed to lessen the burden imposed by the sanctions. However, since the election of President Rouhani, this posture began to be altered, seeking to approach the western countries in order to rid Iran from isolation.

\section{KEYWORDS}

Iran; Africa; Iranian Foreign Policy; economic sanctions

Received on May 30, 2017. Approved on June 19, 2017. 